\title{
Subjects and Objects: Material Expressions of Love and Loyalty in Seventeenth-Century
} England

\author{
Angela McShane
}

$\mathrm{F}$

or the governors of early modern England, an awareness of "how the people stood affected to the present State" was necessarily an issue of constant concern. That affection was judged in relation to a Christian Humanist concept of love, which combined the virtuous, physical, and reciprocal passions of caritas, eros, and anteros. ${ }^{1}$ Indeed, love was explicitly and consistently reiterated as being fundamental to the bonding of the disparate and largely volunteer-governed state. Conceptualizing the bonds of loyalty in this way entailed upon both governors and governed a communitarian idea of citizenship. ${ }^{2}$ It was, however, religiously exclusive. While Protestants (preferably Anglicans) had a monopoly on the virtue of love, other religious and national groups, especially papists, Jews, and Turks, were seen as necessarily motivated by the vicious passions of lust and envy and could neither be loyal nor deserving of loyalty. ${ }^{3}$ As philosopher R. E. Ewin argued, loyalty is not itself a virtue: it is a vehicle through which virtues, such as love, can operate and by which the benefits of virtue-for example, feelings of joy or satisfaction-can accrue. ${ }^{4}$

Angela McShane (formerly McShane-Jones) is Tutor in Graduate Studies (post-1600) for the Victoria and Albert Museum (V\&A)/Royal College of Art, History of Design MA, MPhil, and PhD programs. She is based in the Research Department of the V\&A. Thanks to Angus Patterson, Glenn Adamson, Bernard Capp, Joanne Bailey, Ted Vallance, the editor, and anonymous readers of the Journal of British Studies for their kind suggestions and comments.

${ }^{1}$ Venus's child Eros could not thrive until the birth of his brother, Anteros, who loved him in return. See Guy de Tervarent, "Eros and Anteros or Reciprocal Love in Ancient and Renaissance Art," Journal of the Warburg and Courtauld Institutes 28 (1965): 205-8.

${ }^{2}$ See also Rachel Weil, “Thinking about Allegiance," History Workshop Journal 61, no. 1 (Spring 2006): 183-91, who argues that allegiance lay in outward actions and circumstances rather than "in the interior of a person," 184 .

${ }^{3}$ See discussion in Angela J. McShane-Jones, “'Rime and Reason': The Political World of the English Broadside Ballad, 1640-1689" (PhD diss., University of Warwick, 2005), 312-15.

${ }^{4}$ R. E. Ewin, "Loyalty and Virtues," Philosophical Quarterly 42, no. 169 (October 1992): 403-19.

Journal of British Studies 48 (October 2009): 871-886

(C) 2009 by The North American Conference on British Studies.

All rights reserved. 0021-9371/2009/4804-0008\$10.00 
While scholarship on the political contract has relied largely upon secular, rationalized discussions of works by Hobbes and Locke, recent work by Victoria Kahn has recast the nature of the seventeenth-century political contract by tracing the "role of the passions in motivating contractual obligation." In her comparative analysis of political theorists, romance narratives, and conduct literature, Kahn highlights the importance of consent in all contractual relations, whether in the domestic or the broader political sphere, and argues that there was a broadly perceived need to elicit the passion of love. Evoking this mutual response marked the fulfilment of personal or political contractual relations and served to transform "passions into rights."

This conceptual framework illuminates a popular contemporary paradox, further considered below, that aligned political freedom with subjection. The subject was free to choose obligation and deference and did so because motivated by love and the expectation of being loved in return. This did not imply an enslaved subjection to the arbitrary will of the state. ${ }^{6}$ The allegiance offered by the subject to the state was neither unconditional nor irrevocable, and it depended upon the mutual maintenance of affective relations and benefits.

This article investigates how and where the emotive relations between subject and state were forged and the ideas manifested in society at large. It describes an affective economy of loyalty, embodied in cheap and accessible political commodities, namely, decorated objects made of clay, metals, and paper, on which precious household resources of time, money, and emotion were spent. It argues that by inculcating and engendering codes of political love and insinuating them into people's "emotional, sensual, representational, and communicative" lives, "loyal" goods acted as vehicles and texts for what Kahn describes as "the supplementary role of the passions" in "forging political obligation" and the reformulation of "the duty to love" of both subject and king in seventeenth-century England.

Links between objects and politics have already been noted by scholars, such as Kevin Sharpe, Tom Corns and colleagues, and Lois Schwoerer, who argue that the "image doting rabble" of the seventeenth century engaged visually and materially with monarchy through coins, medals, prints, literary texts, and theatrical performances. ${ }^{8}$ Though important, these studies share two key limitations. They portray a passive rather than an active consumption of politically significant goods,

${ }^{5}$ See Kirstie M. McClure, "Cato's Retreat: Fabula, Historia and the Question of Constitutionalism in Mr Locke's Anonymous Essay on Government," in Reading, Society and Politics in Early Modern England, ed. Kevin Sharpe and Steven N. Zwicker (Cambridge, 2003), 317-50; Victoria Kahn, "Margaret Cavendish and the Romance of Contract," Renaissance Quarterly 50, no. 2 (Summer 1997): 527, and Wayward Contracts: The Crisis of Political Obligation in England 1640-1674 (Princeton, NJ, 2004), chap. 2.

${ }^{6}$ See also Quentin Skinner, "Reassessing the Revolution," History Workshop Journal61, no. 1 (Spring 2006): 156-70.

${ }^{7}$ Leora Auslander, "Beyond Words," American Historical Review 110, no. 4 (October 2005): 1016-17; Victoria Kahn “The Duty to Love': Passion and Obligation in Early Modern Political Theory," Representations 68, no. l (October 1999): 84-107.

${ }^{8}$ Kevin Sharpe, "'An Image Doting Rabble': The Failure of Republican Culture in SeventeenthCentury England," in Refiguring Revolutions: Aesthetics and Politics from the English Revolution to the Romantic Period, ed. Kevin Sharpe and Steven N. Zwicker (Berkeley, 1998), 25-56, 302-11; Thomas N. Corns, ed., The Royal Image: Representations of Charles I (Cambridge, 1999); Lois Schwoerer, “Images of Queen Mary II, 1689-95," Renaissance Quarterly 42, no. 4 (Winter 1989): 717-48. 
ignoring the agency that can arise from a subject's interaction with objects. ${ }^{9}$ In addition, far from being available to the rabble, the items they discuss were restricted in social scope: they were produced for a wealthy and informed market, using techniques and forms that required considerable knowledge to appreciate. For example, etched prints used new techniques, were published in limited editions, and could be expensive-costing as much as five shillings, or more, in the seventeenth century. ${ }^{10}$ Cast medals were regarded as significant works of art, and few were produced from a single die. ${ }^{11}$ Though more numerous, struck medals were not available on the open market; they were made of precious metals and were part of a gift economy that sought to secure client-patron relations, especially within the military. Though coins were circulated more broadly, legends were usually in Latin (the interregnum being an exception), and specie of all kinds was often scarce. ${ }^{12}$ New regimes ushered in new coin designs, but people were just as likely to have an old coin in their purse as a new one. Moreover, until 1660, only the higher denominations carried images. ${ }^{13}$ Nevertheless, in higher social circles, coins were used as markers of loyalty. For example, silver coins were sometimes embedded in expensive lead glasses, from which loyal healths could be drunk. ${ }^{14}$

Items such as these could not permeate much below the highest levels of society, but by extending the range of objects under analysis to include quotidian household items (such as earthenware plates and cups, cheap jewelry, and illustrated broadsides), we can shed more light on the dissemination and construction of early modern loyalty across a much wider social scale. Moreover, the gaps in the material record suggest that, in order to garner sufficient active loyalty at the lower social levels, the state needed to establish an unassailable position within the domestic economy and the affective household.

\section{AN "AFFECTIVE ECONOMY" OF LOYALTY: HOUSEHOLD OBJECTS}

The relationship between material objects, the passions, and contractual obligations was deeply embedded within early modern England. From pewter plates in property exchanges to ribbons in betrothal cases, material objects were accepted as

\footnotetext{
${ }^{9}$ Auslander, "Beyond Words," 1017-24.

${ }^{10}$ See Anthony Griffiths, ed., Landmarks in Print Collecting: Connoisseurs and Donors at the British Museum since 1753 (London, 1996); Timothy Clayton, The English Print, 1688-1802 (New Haven, CT, 1997); Sheila O'Connell, The Popular Print in England (London, 1999); John Peacock, "The Visual Image of Charles I," in Corns, Royal Image, 176-239.

${ }^{11}$ See Mark Jones, The Art of the Medal (London, 1979).

${ }^{12}$ H. A. Seaby and P. A. Rayner, The English Silver Coinage from 1649, 4th ed. (London, 1974), 13; P. Nelson, The Obsidional Money of the Great Rebellion, 1642-1649 (London, 1976); D. F. Allen, "The Coinage of Cromwell and Its Imitations," British Numismatic Journal 24 (1941-44): 191-94; Craig Muldrew, “'Hard Food for Midas': Cash and Its Social Value in Early Modern England," Past and Present, no. 170 (February 2001): 78-120.

${ }^{13}$ Seaby and Rayner, English Silver Coinage, 14, 16; H. A. Seaby, Seaby's Concise Catalogue of English Coins (London, 1965), 50, 57, 61; Sharpe, "Image Doting," 32.

${ }^{14}$ See, e.g., lead glass goblet, dated 1684-1700, Victoria and Albert Museum (VAM): C.139-1925, http://collections.vam.ac.uk/objectid/O2498.
} 
proofs of legal contract. ${ }^{15}$ As part of a general increase in manufactures, the period saw a steady growth of ever-cheaper political commodities: from high-end goods of the 1630s to the imaginative varieties of the 1650s-when the possession of royalist objects made a potentially dangerous statement-to the explosion of loyal goods at the Restoration and beyond to the Glorious Revolution. ${ }^{16}$ Thousands of these loyal items have survived. Their cost was as low as their materials and mode of manufacture were cheap, and they promulgated surface messages that were easily understood.

Despite the methodological problems that arise in using anonymous, largely undocumented goods as pathways for accessing popular political mentalities, it cannot be denied that such objects played a significant part in the everyday experience of many thousands of middling or even lower sorts of people. Using a material vocabulary predicated upon customary and fashionable practices, goods, and genres related to courtship, marriage, and maintenance of the household, loyal objects offered sites for the negotiation of obligations between public and private, subject and state. Their varieties of form, combined with a homogeneous visual and textual content, reflected and encouraged a socially widespread conception of political relationships in terms of a loving and companionate marriage. ${ }^{17}$ This implied mutual responsibility, respect, and obligation based on choice and consent-effectively and affectively a contract between subjects and king. ${ }^{18}$

Leora Auslander comments, "it is because things carry such affective weight that . . key transitional moments in the life of an individual and of a societybirths, birthdays, coming of age ceremonies, whether religious or secular, weddings, and deaths-are marked by the transmission of objects." ${ }^{19}$ In seventeenthcentury England, commemorative objects, produced en masse for a burgeoning life cycle-commodity market, frequently incorporated loyal iconographies alongside personal ones. For instance, brass bed-warming pans present a prime example of the material incorporation of affective subjecthood within the bonds of marriage (fig. 1). Around sixty are known, mainly dating from around the midcentury. They

\footnotetext{
${ }^{15}$ For pewter dishes in property exchange, see, e.g., Grant of Land, 14 February 1651/2, DD/E/ 85/3, Nottinghamshire Archives: (1) delivers seisin of premises to (2) by one pewter dish; Attested Copy Grant, April 1763, 1987/4/1 25, Shropshire Archives: Thomas Cranage puts son George in full possession of [all the premises] by delivering to him one pewter dish; Grant of Land, December 1739, Bagshaw Collection C/2542 27, Sheffield Archives; documents relating to land dispute between Mr. Cressett and Mr. Kinnersley, 26 April 1652, Cressett Estate Papers, 5460/7/2/1, Shropshire Records Office: "a pewter dish fell to the lord for a heriot"; Diana O'Hara, Courtship and Constraint: Rethinking the Making of Marriage in Tudor England (Manchester, 2000).

${ }^{16}$ Joan Thirsk, Economic Policy and Projects: The Development of a Consumer Society in Early Modern England (Oxford, 1978), chap. 1.

${ }^{17}$ See Susan D. Amussen, An Ordered Society: Gender and Class in Early Modern England (Oxford, 1988); Anthony Fletcher, Gender, Sex and Subordination in England, 1500-1800 (New Haven, CT, 1995); Rachel Weil, Political Passions: Gender, the Family and Political Argument in England, 1680-1714 (Manchester, 1999).

${ }^{18}$ One ballad, J. P., The Loyal Subjects hearty Wishes to King Charles the Second (London, 1660), brimming with Old Testament references, referred to the patriarchal king: "The King, our nursing father, / he will us cherish' as a 'nursing father." While this was a common biblical trope used by divines in sermons and other writings and expounded into a defense of absolute rule by political writers such as Sir Robert Filmer, it was more exceptional for black-letter ballads, which consistently depicted monarchs as lovers and spouses.

${ }^{19}$ Auslander, "Beyond Words," 1018-19.
} 


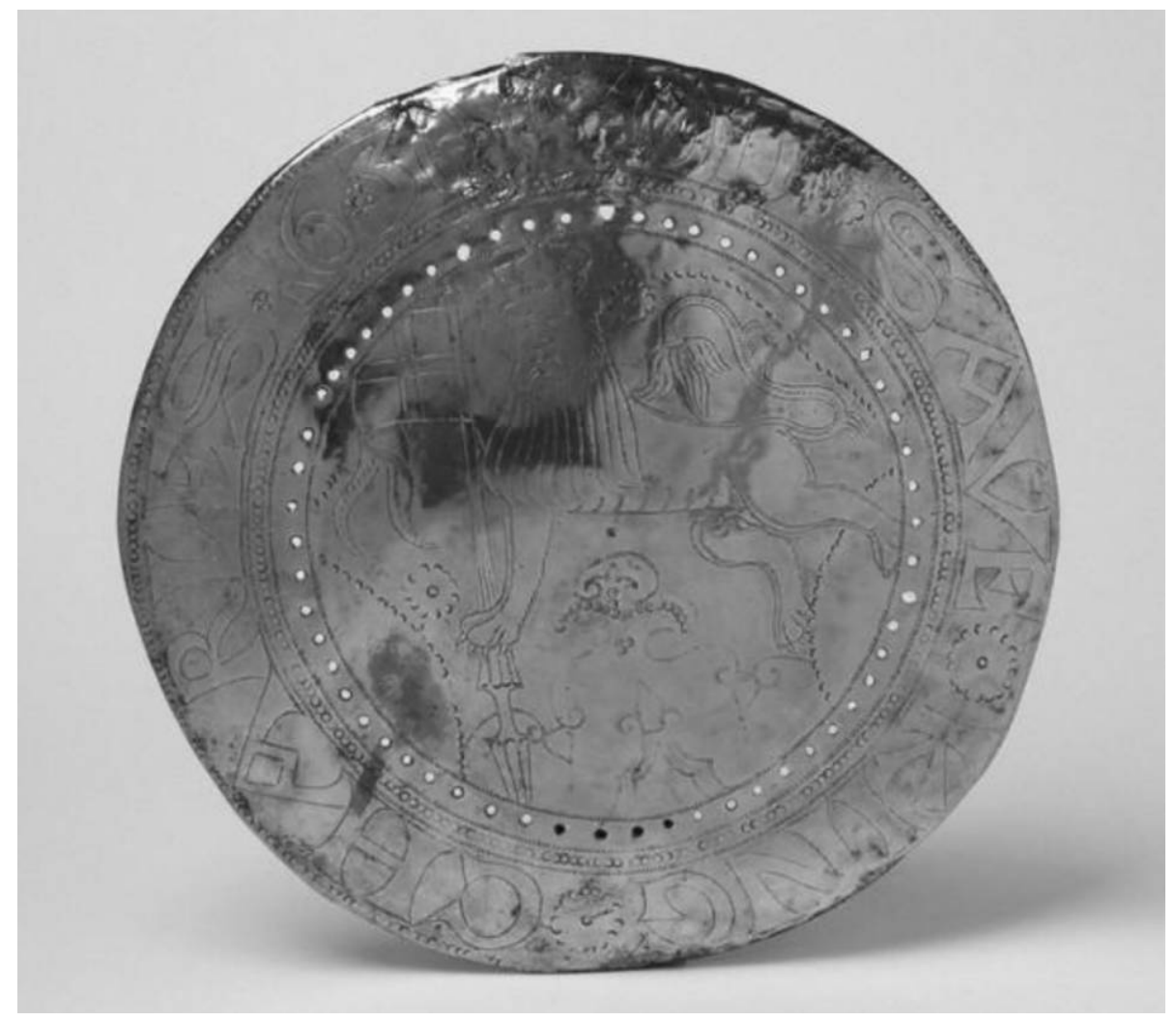

Figure 1-Brass warming pan, English. Inscription: “God Save King Charles 1630.” Decorated with a crowned lion holding a lance with the banner of St. George (VAM: M.42-1932).

were available to the middling sorts, varying in cost from one to several shillings, or more (depending on the quality of material and decoration). ${ }^{20}$ Little is now known of their owners or makers but, judging from the survivals, they were commonly used as vehicles for the declaration of allegiance. Reflecting the overlapping complex of relations any individual or household might have, of the sixty inscribed warming pans currently published, eighteen carried moral or religious mottoes, and five were inscribed with jokes about "Nobody." Six displayed loyalty to identifiable livery companies, and three-dated between 1630 and 1664-portrayed the arms of the earls of Worcester, Derby, and Essex, perhaps indicating military allegiances. At least seventeen were decorated with loyal mottoes or iconographies related to royalty. Most date from 1614 to 1662 , but at least one was dedicated to William III. Many of the remaining warming pan decorations are not easily identifiable. ${ }^{21}$ The domestic function of these objects was to warm the marital bed,

${ }^{20}$ Thefts show costs ranging from 1s. in the sixteenth century to $1-2 \mathrm{~s}$. in the eighteenth.

${ }^{21}$ E. E. Hopwell, "Summary of a Discussion on Warming Pans at the 1991 Meeting," Base Thoughts: The Journal of the Antique Metalware Society, no. 4 (Spring 1992): 11-28; Roderick Butler, "Further Notes on Warming Pans," Antique Metal Ware Society Journal 1 (June 1993); Christopher Bangs, "Note: Inscriptions on English Warming Pan Lids," Antique Metal Ware Society Journal 3 (June 1995). 


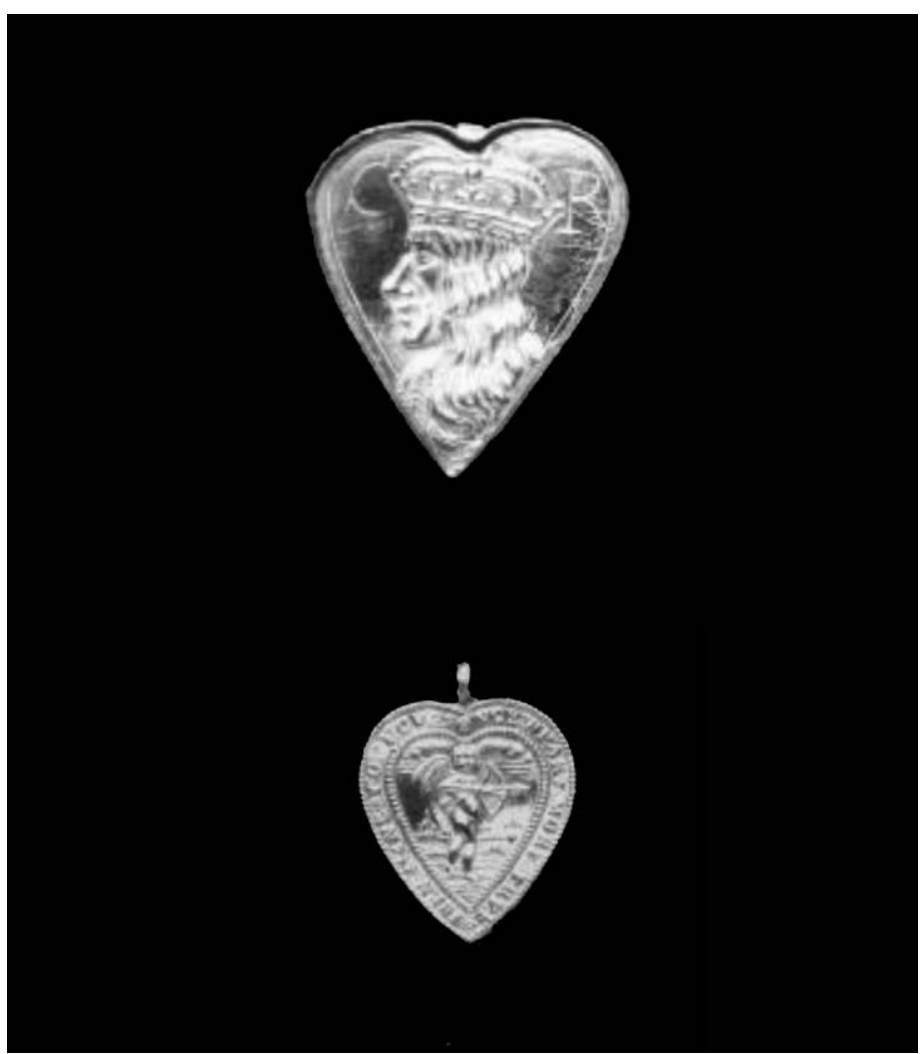

Figure 2-Martha Edlin's heart-shaped silver lockets: top, decorated with crowned male and female heads on either side, inscribed "CR" on one side (VAM: T.437-1990 2); bottom, decorated with figure of Cupid, inscribed "Noe heart more trve then mine to yov"; maker: R. A. (VAM: T.452-1990).

bringing objects of loyalty directly in contact with a major site for contractual fulfilment of fundamental social significance. ${ }^{22}$

Courtship gifts, such as silver lockets, offer another instance of affective interpenetration between public and private spheres. Weighing almost nothing and cheap enough for the middling sorts, they were designed to declare intent and to inspire a response from the recipient, leading to the formation of a successful contract. ${ }^{23}$ Many anonymous examples survive, but two can be definitively attributed to an owner: Martha Edlin, born in London and married to a London merchant in the 1660s. Among the needlework and miniatures in her juvenile casket are two heart-shaped, silver lockets (fig. 2). ${ }^{24}$ One depicts the heads of

${ }^{22}$ Angela McShane and Joanne Bailey, "The Bed as Icon of the Early Modern Household" (paper delivered at the Economic History Conference, March 2007).

${ }^{23}$ Silver was about 5 s. per ounce, but these lockets weighed next to nothing; Nelson, Obsidional Money, 9; VAM: M.3-1958.

${ }^{24}$ See Leigh Ashton, "Martha Edlin: A Stuart Embroideress," Connoisseur 81 (1928); Hannah Kauffman, "Unpicking the Feminine: A Seventeenth-Century Embroidered Casket" (MA diss., Victoria and Albert Museum/Royal College of Art, 2006). 
Charles II and his bride, Catherine of Braganza; the other is decorated with a Cupid and a love motto. ${ }^{25}$ We cannot say with certainly when or how Martha obtained these lockets, but she kept them together, and both show signs of being worn. They were at the same time an intimate and public declaration of mutual affection. ${ }^{26}$

From the 1650s, delftware, or "gallyware," became popular and cheaply available. Several manufactories were established in London and by the 1690s in Bristol. ${ }^{27}$ Pewter was also becoming increasingly ubiquitous. ${ }^{28}$ More marriages than ever were commemorated with cheap, personalized items, including slipware mugs and cups, earthenware jugs and chargers, wriggle-work pewter tankards, and engraved glasses. By combining the new couple's initials with royalist or patriotic imagery (fig. 3), such objects expressed the engagement of the newly formed household with the state. Although purchased to commemorate a single moment, these items retained significance over the entire length of the marriage they celebrated. Equally, many outlasted the regimes they depicted and were kept as heirlooms. By late in the century, loyal delftware charger plates became commodity tropes, being produced in large numbers as a matter of course at the accession of new monarchs, making it perfectly feasible for households to update their loyal objects with one representing the new monarch. ${ }^{29}$ However, it would appear that not all Stuart monarchs were marketable as loyal decorative schemes.

Many royalist objects were produced during the interregnum, though not without risk. In 1660 Thomas Rugge noted that "The picture of Kinge Charles the Second was often printed and set up in houses, without the least molestation, for whereas [before] it was almost a hanging matter so to doe." ${ }^{30}$ The experience of war much enhanced the value of royal memorabilia, as from that time onward cheap loyal objects proliferated throughout the reigns of Charles II and of William and Mary. In contrast, between 1685 and 1687, the quantity and variety of such goods seems to have slumped. ${ }^{31}$ Cheap, prerevolution jewelry, mugs, glasses, or tankards are notable only by their virtual absence, even when taking into account the brevity of James II's reign. Two James II delftware plates have been located, but both were made in Bristol, which began production only after the Revolution. The only warming-pan connected with James II was the fictional one in which his son was supposedly smuggled into the queen's bedroom. Yet from 1689 onward there was another enormous boom in political commodities of every kind depicting the new king and queen. This suggests that, during his reign, ordinary people

\footnotetext{
${ }^{25}$ For further examples, see the V\&A Web site, under "Search the Collections," http://collections .vam.ac.uk/objectid/O77746.

${ }^{26}$ Numerous loyal objects were owned or made by young females; see, e.g., Joan Bacon's 1667 trinket box, VAM: M.826:1\&2-16, http://collections.vam.ac.uk/objectid/O78640.

${ }^{27}$ See Frank Britton, London Delftware (London, 1987); Catalogue . . . of hardpaste porcelain and delftware . . manufactured . . . in Bristol (Bristol, 1875), 6. Leslie B. Grigsby, The Longridge Collection of English Slipware and Delftware (London, 2000).

${ }^{28}$ Mark Overton, Jane Whittle, Darron Dean, and Andrew Hann, Production and Consumption in English Households, 1600-1750 (London, 2004).

${ }^{29} \mathrm{~A}$ full range can be seen in the collections of the V\&A and the Museum of London.

${ }^{30}$ William L. Sachse, ed., The Diurnal of Thomas Rugg, 1659-61, Camden, 3rd ser., 91 (London, 1961), 73 .

${ }^{31}$ Expensive items such as miniature enamels and painted and engraved portraits do survive, although their exact dating is uncertain. See, e.g., http://collections.vam.ac.uk/objectid/O77787.
} 


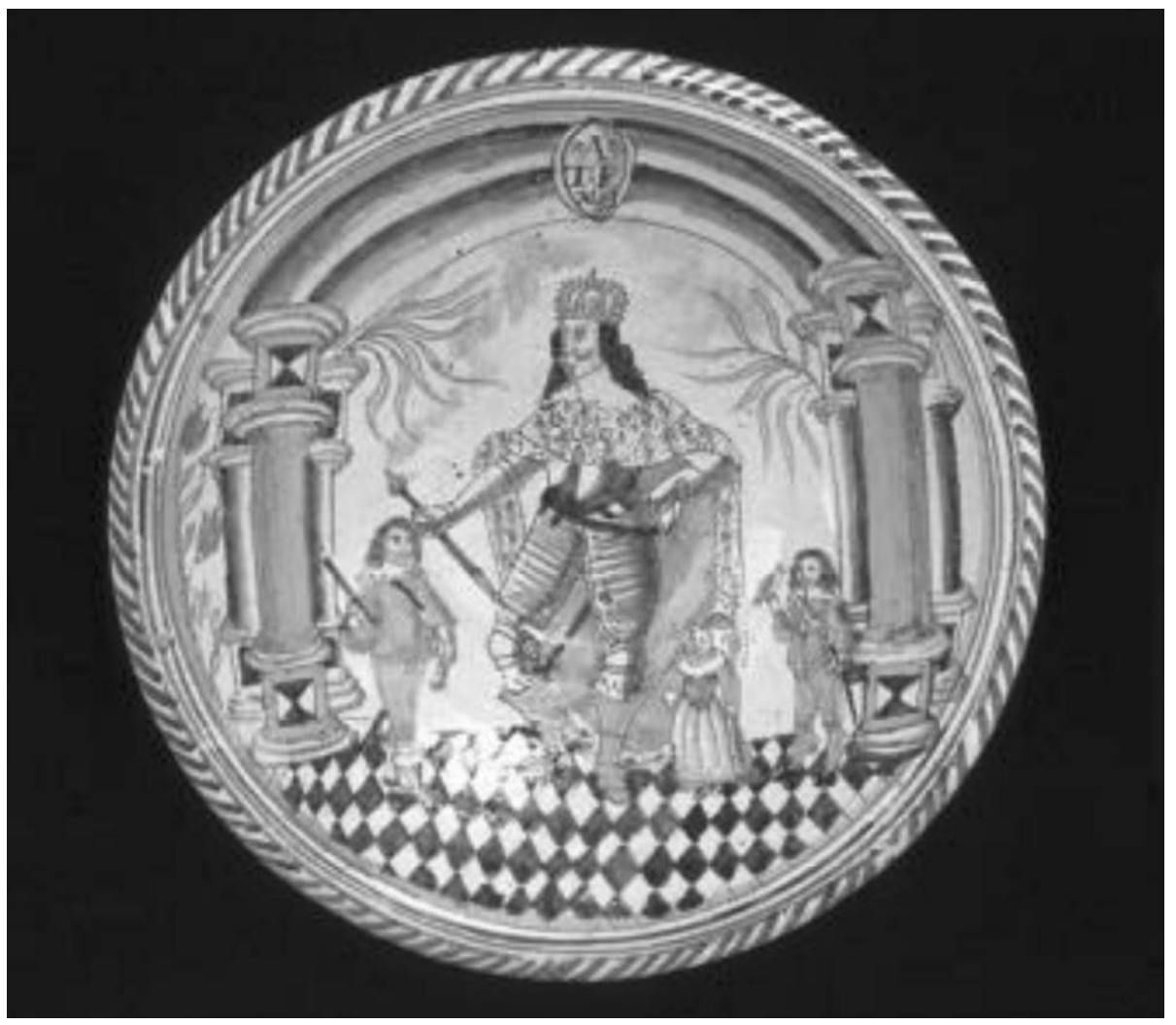

Figure 3-English delftware, or "gallyware," charger, dated 1653. Commemorating unknown marriage of A. \& T. E. (VAM: C.71-1998).

preferred not to incorporate the Catholic James II into their household economies, while many hundreds of people felt sufficiently engaged with the new Protestant regime to bring its motifs into their homes.

Like the household items discussed above, but at the very bottom of the market and accessible to all sorts in society, illustrated broadside ballads were decorative objects that offered both visual and textual political commentary at a cost of less than a penny. Ballads were exchanged as expressions of love between lovers, friends, and family, and, since most were love songs, they were ideal vehicles through which to promote an affective relationship between subject and state. Though cheap and ubiquitous, for the lower sorts ballad sheets were hardly mere ephemera. Paper was precious, and the images on ballads were highly valued. Not only kept as treasures in pockets or books, ballads were also used to decorate walls, chests, and drawers. ${ }^{32}$ For example, six Restoration ballads were found pasted onto a contemporary box lid, in imitation of the marital cassone tradition. This meant that, like plates, ballads remained current and significant long after the moment of their production and purchase.

\footnotetext{
${ }^{32}$ Tessa Watt, Cheap Print and Popular Piety, 1550-1640 (Cambridge, 1991), chap. 5.
} 


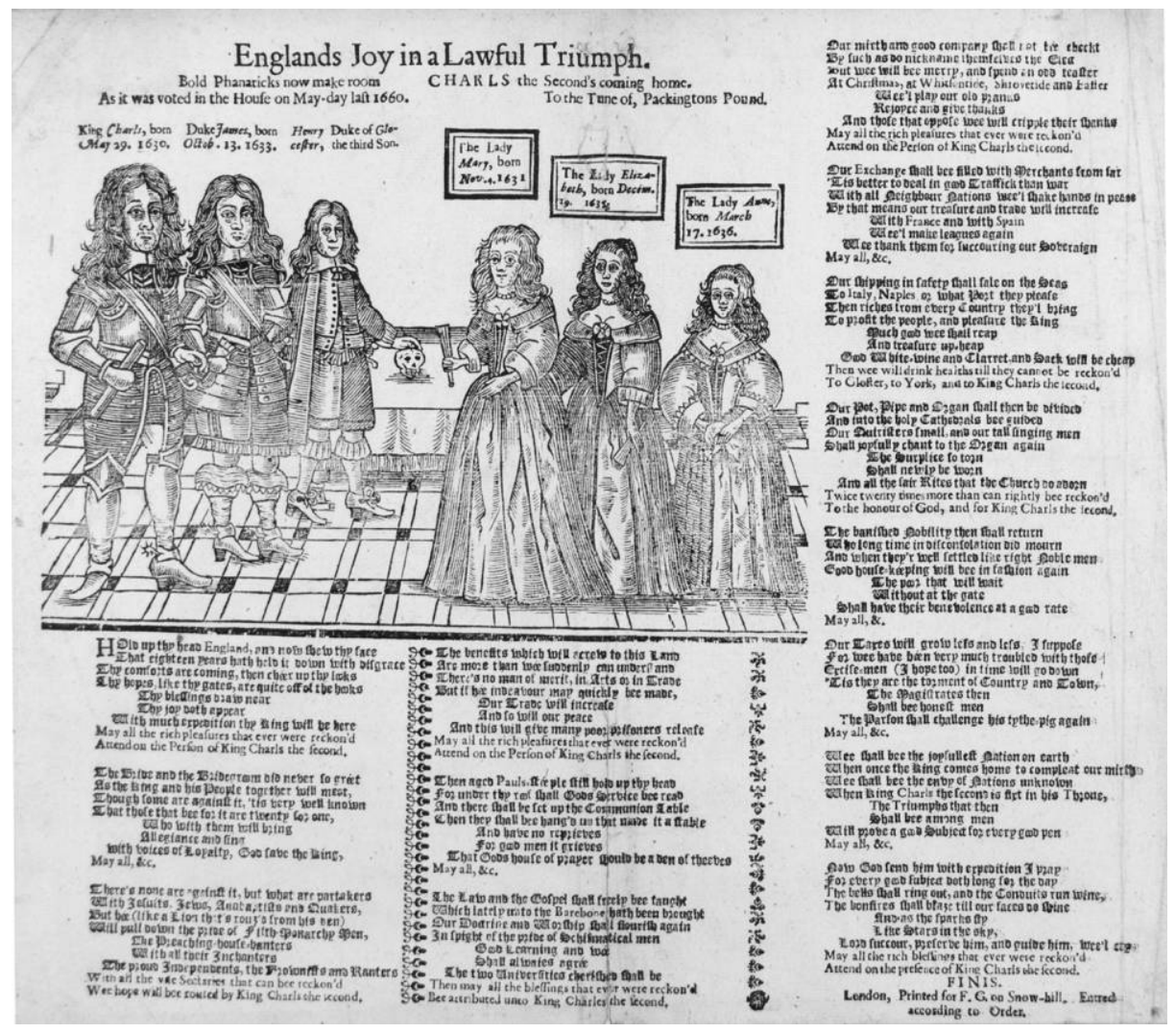

Figure 4-Anon., Englands Joy in a Lawful Triumph (London, 1660). Euing Collection, No. 98. By kind permission of the University of Glasgow.

Ballads were a prime source for disseminating images of monarchy, though they were far from offering straightforward representations of individual monarchs or political figures. The state had no legal control over the use of the royal image in England, and it suffered as a result. Printers drew from a stock of generic "royal" woodcuts, which copied or adapted existing prints of European emperors, kings, and queens. Although images of English royalty were updated during the century and were stylistically similar to those found on other vernacular objects of the period, printers continued to use the older images either alone or in conjunction with newer images. Recognizably royal figures did gaze out at buyers from ballads on political subjects, but they were most often to be found, representing authority and sympathy, on nonpolitical ballads that offered moral advice or warnings about love. There is insufficient space here to discuss in depth the complexities of political ballad illustration in the period, but, broadly speaking, woodcuts based on images of James I appeared throughout the century on a whole range of ballads. Images of Charles I appeared more rarely and mainly after 1659, but many newly fashioned woodcuts of Charles II and his family, legitimate and illegitimate, were created and reused from the 1660s on (fig. 4). Likenesses of James II and his second wife, 
Mary of Modena, were also used — and abused — but perhaps the most ubiquitous figures to appear on ballad sheets were William III and Mary II. ${ }^{33}$

In addition to bringing kingly images into the household, often in the context of a love song, political ballad texts explained and set contexts for the affective relations that the loyal objects discussed above embodied. Influenced by the Aristotelian formulation that only lovely and loving kings could be loved, balladeers explicitly set out the terms of a political contract, as other loyal objects did tacitly, based on choice: emphasizing the mutual "goods" that affectionate subjects and king brought to each other. ${ }^{34}$ This analysis was particularly prevalent at times of change in the regime, most especially the Restoration and the Glorious Revolution, the focus of the discussion below.

For the period 1639-48, illustrated political ballads survive only in small numbers, and few expressed support for the king, but balladeers were stirred by the execution of the "Sweet Prince of Love" in 1649. They envisaged the event as the removal of the heart from the body politic and with it all the affects of good government. ${ }^{35}$ During the Interregnum, royalist ballads lamented the absent lover and master of the kingdom, Charles II. ${ }^{36}$ Between November 1659 and March 1660 , a relative flood of sixty illustrated ballads appeared, arguing for a restoration of the relationship between subject and monarch and laying out the terms on which such an emotional rapprochement could take place. ${ }^{37}$

Love lies a Bleeding unfavourably compared the republican regimes of the past ten years with the universally approved model of properly constituted, affective government when "Betty rul'd Brittain . . .," "Love did nourish [, and] England did flourish." ${ }^{38}$ The balladeer avoided naming any previous Stuart monarch, but personified Charles II as "Love" in order to explain "What sorrow we suffer since Love left the Land":

The low land the high land

And my land and thy land

Grew all in a common strait, when love had left this land

Where Peace is panting

And rage is ranting

'Tis an undoubted sign, the King of Love is wanting.

The ballad argued that only a loved and loving king "can present yee / with peace and plenty." Only "Love" could staunch England's wounds, while "the sword" merely "plasters disasters." "Then let us not doubt it / but straight go about it / To bring in love again / we cannot live without it." ${ }^{39}$

\footnotetext{
${ }^{33}$ Angela McShane-Jones, "Revealing Mary II," History Today 54, no. 3 (March 2004): 40-46.

${ }^{34}$ Aristotle, The Nichomachean Ethics, bk. 8, trans. David Ross, revised by J. L. Ackrill and J. O. Urmson (Oxford, 1980).

${ }^{35}$ King Charles His speech, and last Farewell to the World (London, 1649).

${ }^{36}$ Ladies Lamentation for the Losse of her Land-Lord (London, 1651); T. R[obins?], Jack The PloughLads Lamentation (London, 1654); L. P[rice], The Matchless Shepheard, Overmatcht by his Mistress (London, 1656).

${ }^{37}$ For a complete list, see Angela J. McShane, Political Broadside Ballads of Seventeenth-Century England: A Critical Bibliography (London, forthcoming).

${ }^{38}$ See Judith M. Richards, "Love and a Female Monarch: The Case of Elizabeth Tudor," Journal of British Studies 38, no. 2 (April 1999): 133-60.

${ }^{39}$ Love lies a Bleeding (London, ca. 1659-60).
} 
Balladeers emphasized the new king's lovely person and his loving, loveable nature. In words and image, they pictured and described the king as lovely to behold, with a "rosie face" and "lovely brow" and possessed of attractive virtues. ${ }^{40}$ One ballad contrasted the beauty of the king with the ugliness of Cromwell, claiming that the color of the army's coats had been "called from Cromwell's nose" but could now be called "from Charles his rose." ${ }^{41}$ Balladeers also claimed that the king's chief desire was to make his people love him. Referring to the Declaration of Breda, one ballad asserted, "For his subjects welfare is all his joy / by his declaration at large you see"; another agreed: "his subjects his charge will be / and his care for their safety . . . will prove / his joy to be our love."42 The praise of the merry Month of May promised that Charles was the ideal lover for the nation. He was lovely: "like to a 'tractive sympathy," a "nymph" and a "flower / to perfection brought." He was loving: "By Love hee'l rul more than by Law." And he would make himself loved: "all our rights he will so wel maintain / whereby our hearts to him he'l draw." 43

As with the lockets discussed above, ballads were frequently used as love gifts, while their texts constructed the political relationship as a courtship. This created a key role for the prospective "bride," who could weigh up the virtues of her suitor and decide if he would protect her material, emotional, and spiritual needs. Ballads reiterated that the king was subject to the "choice" and "consent" of all key parties. One ballad brought "Tidings of chusing now a King / whereby true subjects may rejoice / In chusing them so sweet a choyce / That love and peace may so agree / to end the days of misery." ${ }^{44}$ Another rejoiced "that peace and truth it may bear sway / Being the election of that thing / In chusing us a Royal King . . . wherein they will so well agree / that we shall live in unity." ${ }^{45}$ The intriguingly entitled Englands Captivity Returned proclaimed England's "ready obedience" to "bring home the King" as "the only thing / could make all things well for the people." ${ }^{46}$ However, as Ralph Josselin observed on 25 December 1659, "the nacion look[ed] more to Charles Stuart, out of love to themselves not him." ${ }^{47}$ Only by winning hearts would a king's people love him and obey, and these could only be won if the mutual interests of both parties were served.

Ballads assured the nation that real benefits, physical and emotional, would follow the union of king and parliament. During the Interregnum "sad excises [had] been so rife / it hath beggar'd man and wife," but now a domestic recovery was predicted, for "honest men [shall have] their lost estates / maydens shall have their mates, wives their husbands" and "all unto their trades may fall / their families

\footnotetext{
${ }^{40}$ See fig. 3; Untitled Ballad, Crawford Collection, National Library of Scotland, no. 990 (1660); A. Starkey, Good News for England (London, 1660).

${ }^{41}$ The Case is altered (London, 1660).

${ }^{42}$ Englands honour, and Londons glory (London, 1660); A Worthy Kings Description (London, 1660). See also J. P., Loyal Subjects hearty Wishes.

${ }^{43}$ The praise of the merry Month of May (London, 1660).

${ }^{44}$ Gallant News of late I bring (London, 1660).

${ }^{45}$ Englands rejoycing at that happy day (London, 1660); see also The Royall Subject's Joy (London, $1660)$.

${ }^{46}$ Englands Captivity Returned, With a Farewel to COMMON-WEALTHS (London, 1660).

${ }^{47}$ The Diary of Ralph Josselin, 1616-1683, ed. Alan MacFarlane (London, 1976), 457-58.
} 
for to maintain." ${ }^{n 8}$ Good feelings would then follow: The Royall Entertainment claimed "our sorrow and grief is turn'd to relief / and comfort is now our Commander in Chief." ${ }^{49}$ Ballads told how "The King and Parliament now are agreed / to ease our sadnesse / free us from all annoy . . . for they will suffer none us to destroy / the which doth both our joy and comfort breed" and promised that "Love will nourish us so / we shall know no wo."

Having elicited reciprocal feelings of love, Englands Joy anticipated that "The Bride and the Bridegroom did never so greet / As the King and his people together will meet." ${ }^{51}$ Like a bride, using her reasoned free will in her promise to "obey and serve . . . love honour and keep" her husband, the people gave free consent to their subjection. One balladeer looked forward to the time when "Wars shall end / then I and my friend / a subjects freedome shall obtain." ${ }^{52}$ But the bridegroom also made promises: to provide, to "comfort," and to "honour," and most importantly he accepted a duty to love. ${ }^{53}$

Consent to subjection was based on a respect for, not an abnegation of, the people's rights. Balladeers agreed that the acceptance of the king was by no means unconditional. When the Long Parliament was recalled, one ballad urged General Monk, "Govern thou us by rightful laws / exclude us not from / Our just rights in any cause." ${ }^{54}$ Willing to have "no King but the old King's son," The Covenant nevertheless declared that the army had fought "for the subjects liberty" and prayed, "Great Jove unite our hearts together / our privileges to maintain." 55 The Royal Subjects Joy called upon "all true subjects" to stand "for peace and liberty ... . for the good of fair England." Even the most laudatory ballad, describing the fullest extent of the king's power, openly stated conditions. A Worthy King described the king as "Gods vice-regent" and declared that "his wants must be supplyed / no place unregarded / but royally rewarded / richly his state [to] maintain." But at the same time it promised that "When in fair England he doth reign / all men shall be free / and set at liberty" and that the king would not "delay Gods laws to obey / and all mens rights for to maintain." Further, the balladeer stipulated that the king's command and "power will be absolute" only "if right," adding, "what rightful thing by him is said / ought not for to be disobeyed." $" 56$ The mutuality of this relationship was encapsulated in Englands Joy in a Lawful Triumph (fig. 4):

The King shall his prerogatives enjoy

The state their privilege shall have

He shall not theirs nor will they his annoy

But both each others strive to save.

\footnotetext{
${ }^{48}$ Englands rejoycing at that happy day; Englands Great Prognosticator (London, 1660); The Glory of these Nations (London, 1660).

${ }^{49}$ T. J[ordan], The Royall Entertainment, Presented by the Loyalty of the City . . . (London, 1660).

${ }^{50}$ Englands honour; Gallant News.

${ }^{51}$ Fig. 4; see also Englands honour.

${ }^{52}$ Englands Great Prognosticator.

53 "Of Matrimony," in The Book Of Common Prayer (London, 1663), unpaginated.

${ }^{54} \mathrm{~J}$. W[ade], Englands Heroick Champion (London, 1660).

${ }^{55}$ The Covenant (London, 1660).

${ }^{56}$ A Worthy King (London, 1660); see also Jordan, Royall Entertainment; J. Wade, The King and Kingdoms joyful Day of Triumph (London, 1660); The Royal Wanderer (London, 1660).
} 

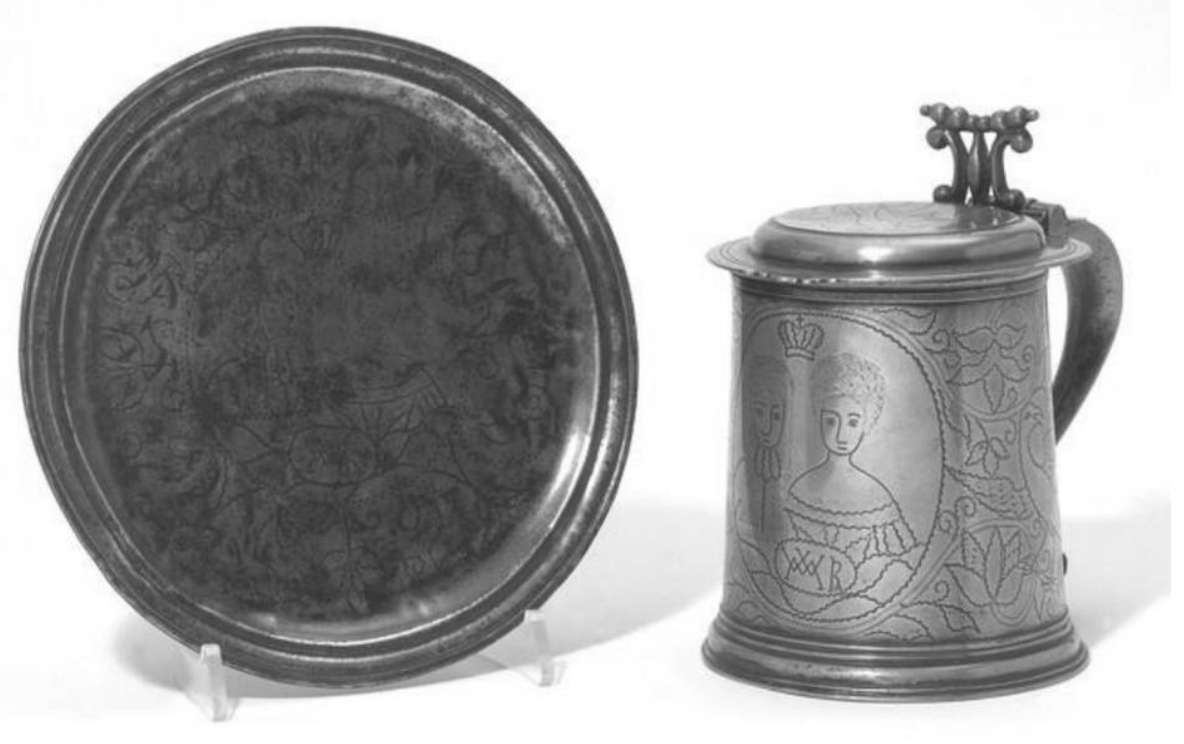

Figure 5-English pewter plate and tankard, with wrigglework decoration depicting William III and Mary II, marked "R. S." (VAM: M.14-1991).

Mutual respect and benefit alone would ensure that "Parliament no more in arms against a lawful king" would occur.

With the end of Charles II's "honeymoon period," political ballads declined in number (though other objects did not), but they did not cease. On the contrary, balladeers continued to use discourses of love, even unrequited love, to describe relations with him and his illegitimate, but Protestant, son James, duke of Monmouth. However, with the accession of James II, balladeers changed their tune. As with other objects, considerably fewer political ballads seem to have been published in his reign, even at the coronation. These sang of "obedience" rather than love, and the legitimacy, rather than loveliness, of the king. ${ }^{57}$ Material expressions of love and loyalty reappeared only at the Glorious Revolution, when political commodities of all kinds again proliferated. Plates, cups, glasses, tankards, and political ballads decorated with new images of the royal couple abounded, bringing them into the heart of households across the country (fig. 5).

Ballads represented William and Mary as the model of a loving couple who shared between them the defense and care of the country. Faced with the disastrously foreign, ungainly, and taciturn William, balladeers nevertheless attempted to present him as accessible and loveable, even hinting that he had an English sense of humor. One ballad, describing an amusing (fictional) meeting between the king and a farmer, reflected:

\footnotetext{
${ }^{57}$ Angela J. McShane-Jones, “'England's Darling' or 'Senseless Loon': Hero and Villain, the Ballading Battle for the Image of Monmouth," in Heroes and Villains: The Creation and Propagation of an Image, ed. C. H. L. George and Julie Sutherland (Durham, 2004), 139-57; McShane-Jones, "Rime and Reason," 349-58, 222-31, 381-87, 389-96.
} 
These were happy days, when Great Caesars would be Familiar with Subjects of ev'ry degree.

Yet those that have govern'd these Kingdoms of late, Have not been so pleasant, till William the Great.

It concluded that "Great William," who had "venter'd his life to pull popery down," was "beloved by the best of the town." 58

Mary more than made up for William's flaws, however. Depicted from the outset as a "vertuous wife in all her ways," young, beautiful, Protestant, and of "the right line," she was the lovely and loving face of the monarchy until her death in $1694 .{ }^{59}$ Balladeers praised her kindness and beauty, while her adroit managing of government during William's absences increasingly impressed them. ${ }^{60}$ At first, ballad dialogues depicted a loving but helpless Mary who tried to prevent her husband from going to war, but they soon became political discussions between a capable regent and the warring king. ${ }^{61}$ By giving expression not only to the deep affection between the royal couple but also to the real fears and experiences of many men and women in wartime England, the texts and images of these ballads created a tremendously sympathetic, accessible, and loving image for the royal couple.

\section{CONCLUSION}

While loyal objects were designed both to express and to evoke love and loyalty, it is, of course, problematic to make straightforward connections between the ownership of such objects and political views. Some individuals owned objects reflecting mixed loyalties. ${ }^{62}$ Moreover, bringing representations of the monarch under one's roof offered numerous subversive possibilities. So much depended on how loyal objects were used, where they were placed, and the public nature of the domestic space into which they were brought. How, for example, should we interpret the 1686 example of a "bleeding bowl" decorated with an image of James II ${ }^{63}$ Was it used as a public declaration of loyalty in a barber surgeon's

\footnotetext{
${ }^{58}$ The Royal Frolick (London, 1689/90). Several ballads following this story were printed.

${ }^{59}$ See Great Britain's Earnest Desire for the Princess Mary's Happy arrival (London, 1689); The Princess Welcome to England (London, 1689); The Kingdom's Joy for the Proclaiming King William and his Royal Consort Queen Mary in the Throne of England (London, 1689); The Subjects Satisfaction (London, 1689); England's Triumph (London, 1689); England's Extasie (London, 1689). Her virtues were also praised, and to some extent the effect of her childlessness relieved, in ballads such as The Bedfordshire Widow (London, [1690s]), which compared Mary to "Dorcas the Good" as she saves the life of a widow and her three orphans, and The Distressed Mother (London, 1690s), in which a little girl is left at the court for Mary to bring up.

${ }^{60}$ William had overruling power, but the 1690 Regency Act gave Mary authority. She ruled for thirtytwo months.

${ }^{61}$ Schwoerer, "Images of Queen Mary II," 717-48, sees the Regency Act as the key moment in this change, which is reflected in a range of media other than ballads. See The Royal Dialogue (London, 1690); King William's Courage (London, 1690); The Royal Farewell (London, 1690); The Protestant's Joy (London, 1690); and The Courtly Salutation (London, 1690).

${ }^{62}$ See, e.g., Inventory from Coker Court, 1723, DD/WHh/1106, Somerset Record Office: listed in the study "one gold coronation medall, King William and Queen Mary"; in the lobby "Picture of King James 2nd, Framed."

${ }^{63}$ F. H. Garner and Michael Archer, English Delftware, rev. ed. (London, 1972), 14, plate 32b.
} 
shop, as a private reflection on the bloody popery of the king, or simply as a joke for a customer to imagine bleeding over the king's face? Objects like these, perhaps produced in large numbers, probably played a variety of conflicting roles in different contexts and at different times.

Nevertheless, consideration of loyal objects does allow us to reconsider contemporary ideas of subjection and political agency. As Kahn points out:

Faced with the problem of voluntary servitude [early modern theorists] illustrated that right sort of subjection by comparing the political contract . . . to the marriage contract, the voluntary subjection of the contracting subject to the voluntary subjection of the wife in marriage. In so doing they unwittingly feminized the subject of contract . . . the instability of these discourses was intensified by the very public nature of the conversation: the very fact of debating the nature of the will, the liability of the passions, and the meaning of consent, insinuated the possibility of individual agency and constructive change even when the ostensible topic was the bondage of the will. ${ }^{64}$

This has particular significance when we take into account the fact that so many loyal objects were geared toward a female, domestic market, and numerous items can be shown to have belonged to young women on the brink of marriage. In the same way, ballad discourses complicate any straightforward reading or gendering of the body politic. ${ }^{65}$

Loyal objects and discourses domesticated the monarchy, bringing the state within the purview of family relations and exposing them to the same mutual imperatives of Christian Humanist love. A "duty to love" was far more than mere rhetoric in lived experience. In England, marriage was supposedly an indissoluble contract, but in everyday life marriages suffered constant tensions, and official separations of bed and board were common where marital relations appeared irrevocably broken down. ${ }^{66}$ No great intellectual leap was needed to suggest that a similar separation might be necessary should king and people fall out of love.

The languages of love and the mutual obligations of marriage as expressed through the rhetorics of political commodities are material demonstrations of Kahn's argument that "the constitution of the affective subject is central to early modern contract theory." Because of the explosion of cheap loyal goods, the Restoration was a turning point in making the terms of the affective relationship between subject and state explicit at every social level. The success of the loyal commodity market, and perhaps the regime, depended on the ability of the monarch to engage the love and good will of his subjects. Based on the material evidence, while Charles II and William and Mary were salable, James II was an unloved, unloving, and unlovely king. As a papist and an authoritarian, he lacked the appeal with which to engage the affections or pockets of his subjects. Political

\footnotetext{
${ }^{64}$ Kahn, Wayward Contracts, 59-60.

${ }^{65}$ See Bernard Capp, When Gossips Meet: Women, Family, and Neighbourhood in Early Modern England (Oxford, 2003), 290-319, 347.

${ }^{66}$ Lawrence Stone, Road to Divorce: England, 1530-1987 (Oxford, 1990); Joanne Bailey, Unquiet Lives: Marriage and Marriage Breakdown in England, 1660-1800 (Cambridge, 2003).
} 
commodities acted in the negotiation of intensely personal and mutually binding relationships between subject and state, by materializing the expectations, rights, and free choice of individuals and by making it imperative for a king to maintain the affections of his subjects. 